\title{
An Examination of the Relationships Between Different Types of Innovation and Firm Performance and the Mediating Effect of Radical and Incremental Innovations on These Relationships
}

Tope Samson Abiodun

College of Management \& Social Sciences, Department of Business Administration, Kwararafa University Wukari, Taraba State, Nigeria

\begin{abstract}
The long-term vector, an area of macroeconomics that is known as economic growth, is driven by innovation and entrepreneurship. Entrepreneurial scholars have contended that types of innovation vary and contingent on the object, the sector and intensity. Building on this assertion, this study examined types of innovation that could have significant impact on firm performance, considering the liability of smallness of SMEs in developing economy. Having employed PLS-SEM on data collected from SMEs in Nigeria, the results of the study suggest product innovation, process innovation and administrative innovation are statistically significant and positively related to firm performance. Radical innovation mediates the relationship between process, product, administrative innovation and firm performance. Incremental innovation mediates the relationship between process, product and firm performance. While the study finds no support for the proposition that incremental innovation mediates the relationship between administrative innovation and firm performance.
\end{abstract}

Keywords: Radical innovation, Incremental innovation, Product innovation, Process innovation, Administrative innovation, Firm performance.

\section{Introduction}

A lot has been written on the subject of innovation. More than 250 books were published with the word "innovation" in their title in just the first 3 months of 2012, and the term appeared more than 33,000 times in 2011 alone, in the annual and quarterly reports filed with the US Securities and Exchange Commission (SEC), a 64\% increase from 2006 (Kwoh, 2012). Firms have been prompted to search for competitive advantage for survival due to intense global competition, rapid change of technology and higher consumers' demands (Black \& Synan, 1997). To be more competitive and to survive in global business world today innovation is regarded as an important mechanism (Salaman \& Storey, 2002). Innovation is paramount for growth and competitiveness (Scholl, Rubik, Kalimo, Biedenkopf, \& Söebech, 2010)

The long-term vector, an area of macroeconomics that is now known as economic growth, is driven by innovation and entrepreneurship while a large number of other factors such as monetary and fiscal policies, budget and trade deficits, inflation, unemployment, exchange rates, and several others affect the economy in the short term. Innovation in United States gave birth to new industries such as computers, semiconductors, lasers, and wireless and optical communications. The emergence of new innovation and value creation could be seen in USA through companies such as Apple, Google, Amazon, eBay, Face book, Twitter, and many other new innovative entrants in the software and Internet arena, as well as leader in other sectors 


\section{Tope Samson Abiodun}

An Examination of the Relationships Between Different Types of Innovation and Firm Performance and the Mediating Effect of Radical and Incremental Innovations on These Relationships

such as biomedical instrumentation, pharmaceuticals, nanotechnology and biotechnology (Christensen \& Raynor, 2013). While enterprises played more of a role in technological innovation, and more than 500 technological business incubators were set up in 2004 in China (ZHANG \& ZHU, 2007).

Innovation could be described as the specific tool of entrepreneurs, the technique by which they exploit changes and opportunity for a different business. Innovation is a process for creating and introducing something new, novel, or advanced with the intention of creating value or benefit (Kearney \& Hisrich, 2014). It is a process that begins with a new idea and concludes with market introduction. An entrepreneur is required to search with determination for the sources of innovation, changes and symptoms that indicate opportunities for successful innovation, and needed to know and apply the principles of successful innovation (Kearney \& Hisrich, 2014).

Innovation distinguishes from invention because innovation as a specific social activity is carried out contained by the economic sphere and with a commercial intent, whereas inventions could be implemented without any commercial purpose (Kenney \& Patton, 2009). Hence, innovation is a combination of novelty, meaningfulness, and resources subject to commercialization (Schumpeter, 1934). It is about new business opportunities created through new technologies, products, services, processes, and business models. Innovation is not something that just happens by itself, but a structured or systematic process that requires discipline and that can be learned and practised. Therefore, to succeed at innovation an entrepreneur is expected to be proactive and search for the sources of innovation and exploit it (Hisrich and Kearney, 2014). An internal stock of scientific knowledge is created when a firm invests in R\& $D$ that may further lead to global knowledge diffusion (Buckley \& Ghauri, 2004). Subsequently, improved corporate revenues and performance are realized in turn, when firm develops and introduces new products to the market (Kafouros, Buckley, Sharp, \& Wang, 2008).

Innovation is a process for creating and introducing something new, novel, or advanced with the intention of creating value or benefit (Kearney \& Hisrich, 2014). It is a process that begins with a new idea and concludes with market introduction. However, strategic literature proposes that SMEs could profit by adjusting to environmental changes faster than bigger organizations due to their nimbleness, absence of hierarchies, and prompt decision-making. All these benefits attributable to innovation help SMEs to successfully compete with well-established incumbents that can rely on a much larger resource base than their smaller counterparts. In addition, innovative products may create new demand and, thus, facilitate firm growth. The confidence that general public have towards SMEs culminates to huge investment in innovations than larger organizations (Lee and Chen, 2009). As a result of this, an entrepreneur or small business manager could conclude that innovation benefits new and small firms' development irrespective of their circumstance.

\subsection{Problem Statement}

In developing economy, R\&D activities in different domains especially in science and technological innovation (STI), emanating from knowledge institutions are not adequately utilized (Oyewale, 2005). As such the economy has been dependent mainly on oil and agriculture but with low performance in service and manufacturing SMEs domains. Nigeria largely focuses her resources on imported technologies despite the available human and infrastructural resources than developing own technology. Consequently innovation that would necessitate industrial development towards a knowledge-driven economy would be far from environment where interactions are weak and resources are not properly harnessed.

Innovation capabilities are seen as critical tool in achieving a superior innovation performance. A firm has to be innovative to survive in volatile environment (Calantone, Cavusgil, \& Zhao, 


\section{Tope Samson Abiodun}

An Examination of the Relationships Between Different Types of Innovation and Firm Performance and the Mediating Effect of Radical and Incremental Innovations on These Relationships

2002). Innovation-performance relationship frequently presents mixed findings in several empirical studies. Studies like Birley and Westhead (1990) and Heunks (1998) reported that innovation does not influence firm performance. While some studies like McGee et al., (1995) and Vermeulen (2005) found negative performance implications of innovation. Meanwhile some studies (Deeds \& Decarolis, 1999; Li \& Atuahene-Gima, 2001) demonstrated positive relationship. Hence, innovation-performance relationship could be described as mixed and inconclusive (Li \& Atuahene-Gima, 2001). Besides, this mixed finding was based on unplanned narrative reviews and usually refers to large established firms.

In addition, the context in which the innovating firm operates might affect the outcome an innovation has on the firm (Anokhin \& Schulze, 2009; Droge, Calantone, \& Harmancioglu, 2008; Thornhill, 2006). As well, innovation is phenomenon with many facets (Kleinknecht, Van Montfort, \& Brouwer, 2002; Von Hippel, 1990). Furthermore, firms vary in the amount of inputs they devote to the innovation process. However, the dedication of more inputs to the innovation process does not guarantee innovation outcomes, since the process of developing innovation is complex and characterized by high risks (Wolff, 2007). Thus, the process of the development of innovation needs to be managed diligently in order to increase performance (Howell, Shea, \& Higgins, 2005; Wolff, 2007). If firms devote substantial resources to the innovation process, but are unable to turn them into innovative offerings, resources are squandered and firm performance suffers. The squandering of resources due to improper innovation process management is especially detrimental for SMEs due to their generally substantial resource constraints. If SMEs devote a significant proportion of their resources to the innovation task, yet, are unable to generate a return on their resource investments, their existence and development can be threatened. Based on these arguments associated with the productivity of the innovation process in turning innovation inputs into innovation outputs in SMEs, this study expects that SME performance is influenced more strongly by the amount of innovation outcomes than by the amount of innovation inputs.

\subsection{Aim of the Study}

There is a dearth of studies relating the understanding of the types of innovation that SMEs pursue and their impact on performance. The major objective of this study is to draw some relationships between these types of innovation (process, product, administrative) and firm performance in order to know which innovation types really enhance SME's performance. Secondly, to introduce incremental innovation and radical innovation as mediators to intervene between the relationships between types of innovation (product, process and administrative innovations) and firm performance in order to determine the synergistic effects of intensity of innovation coupled with types of innovations on firm performance. Thirdly, conducting a survey research on SMEs in Nigeria using PLS model to analyze the data collected from SMEs' owner manager and finally report these results and provide theoretical and managerial implication of the findings.

\section{Literature Review}

Types of innovation vary and contingent on the object, the sector and the scope or its intensity which are independent, with recognizable attributes and without dividing lines. They are; Product innovation, Process innovation, Organizational innovation, technological innovation, incremental innovation and radical innovation (Carayannis, Samara, \& Bakouros, 2015a). The first group, when classification is based on the object of innovation is product/service and process innovation. Process innovation occurs when a firm introduces new elements in its production or its operation is being employed or the production of product or the provision of a process (Drejer, 2002). While Product innovation takes place when a firm introduces a new product/service in the market (Carayannis et al., 2015). Generally, the emphasis a firm places on types of innovation always differs but hinges on company stage, for instance when the firm 


\section{Tope Samson Abiodun}

An Examination of the Relationships Between Different Types of Innovation and Firm Performance and the Mediating Effect of Radical and Incremental Innovations on These Relationships

is small, it adopts product innovation as it grows to maturity and becomes more complex, it adopts process innovation (Lages, Silva, \& Styles, 2009).

The second group of innovation - when classification is based on the sector is administrative/ organizational innovation and technological innovation. The administrative innovation occurs when a firm introduces a new administrative system /process; it might not introduce a new product/ service but indirectly influence their introduction or its production process (Garayannis et al., 2015). Administrative innovations are primarily adopted by large enterprises with more complex structures which might have been faced with bigger problems in auditing and coordinating various departments and try to solve such problems through administrative innovations.

Technological Innovation has to do with the technological sectors of an enterprise. It comprises of the equipment and the procedures for raw materials and information transformation into products or services (Feldman \& Florida, 1994). Innovation is technological innovations when it comprises of implemented technologically new products and processes or significant technological improvements in products and processes (Smith, 2005). The characteristics of a technologically new product are a product whose technological feature or intended uses differ significantly from those of previously produced products. Such innovations involve radically new technologies; it could be based on combining existing technologies in new uses, or derived from the use of new knowledge. On the other hand a technologically improved product could be an existing product whose performance has been significantly enhanced or upgraded.

The third group of innovation - when classification is based on the intensity and the scope is incremental innovation and radical innovation. Incremental innovation is relatively small deviation from current practices to improve old products or procedures without necessarily intervening in the existing structure and strategy of the firm. It is innovation that introduces relatively minor changes to the existing product, exploits the potential of the established design, and often reinforces the dominance of established firms (Nelson and Winter, 1982; Tushman and Anderson, 1986). Whereas, radical innovation gives rise to fundamental changes in the activities of an enterprise and expresses a significant deviation from current practices (Koberg et al., 2003). However, firms adopt radical innovation less frequently compared to incremental innovation as it constitutes serious challenges for the existing structure. Radical innovation seems more complicated to the members of an enterprise because it is more original and could provoke higher degree of uncertainty for its stage of development and application. Typically, large enterprises with higher potential success rates than smaller ones might introduce radical Innovations because the type of these innovations requires technical knowledge and stock of resources. Besides, large enterprises possess the financial capability to absorb the largest part of the cost, in the event of failure large enterprises act in a more decisive way (Carayannis, 1994). , Incremental innovation often calls for considerable skill and ingenuity and, over time, has very significant economic consequences. However, the distinction between refining and improving an existing design and introducing a new concept that departs in a significant way from past practice is one of the central notions in the existing literature about technical innovation (Moch and Morse, 1977; Freeman, 1982).

Hence, it can be contended that some forms of innovation might be more beneficial than other forms (Damanpour, Szabat, \& Evan, 1989). Although the literature recognizes a wide range of innovation types within the firm (product/process, radical/incremental, technological/managerial, market pull/technology push, or competenceenhancing/competence-destroying), most of the empirical works use the product process typology (Delgado-Verde, Martín-de Castro, \& Emilio Navas-López, 2011). 


\subsection{The relationship between Innovation and Firm Performance}

The vast majority of the literature reviewed in this study found significant relationship between innovation and firm performance. For instance these studies (Therrient et al 2011:Artz et al., 2011; Jimenez-Jimenez, 2011; Atalay et al., 2013; Hung \& Chou 2013; Ar et al.,2012; Lööf \& Heshmati 2006) found relationship between product innovation and firm performance. Some other studies (Jimenez-Jimenez, 2011; Zeng Xie \&Tam, 2010; Chao and Pucik, 2005; Gronum et al., 2012; Ahn et al., 2014) found relationship between general elements of innovation and firm performance. Similarly, the relationships between technological innovation and firm performance are also evident in some studies (Ar, 2012; Atalay, Anafarta, \& Sarvan, 2013; Hung \& Chou, 2013; Lööf \& Heshmati, 2006; Wang \& Wang, 2012). while some other studies specifically found overwhelming evidence for direct relationship between organizational innovation, administrative innovation and firm performance (Jaskyte, 2011) and another study found significant relationship between incremental, radical innovation and firm performance (Baker \& Sinkula, 2002).

However, some studies did not find significant and positive relationship between innovation and firm performance (Damanpour et al., 2009; Love \& Mansury, 2007). Previous studies usually focus on the innovativeness of the firm, which is to say, on the degree to which the organizational culture promotes and supports innovation (Keskin, 2006; Lee \& Tsai, 2005) or analyzes only one type of innovation, mainly product innovate (Salavou \& Lioukas, 2003). Thus, previous research provides a partial explanation only of the phenomenon of innovation. Studies have presented a list of stylized facts on the relationship between firm size, R\&D effort, productivity and growth. There is an approximately constant relationship between R\&D and patents in the cross-sectional dimension but a negative relationship between R\&D and patents in the longitudinal dimension. Similarly, there is a positive relationship between R\&D activity and the level of productivity across firms, whereas the longitudinal relationship between firmlevel differences in R\&D and productivity growth is typically statistically insignificant (Cohen \& Klepper, 1996; Klette \& Kortum, 2002). While Simpson, Siguaw, and Enz (2006) posited that innovation could be expensive and risky, sometimes with positive outcomes on firm performances at the same time could also have negative outcomes, such as greater than before exposure to market risk, costs' increase, employee dissatisfaction or unnecessary changes. Moreover, some studies considered the liability of smallness between SMEs and innovation performance because of its barrier to innovation such as lack of structural, human and financial resources (Fiegenbaum \& Karnani, 1991; Singh \& Lumsden, 1990). SMEs also suffer from smallness in form of insufficient resources and capability which constitute internal barriers that have impact in innovation more than the large firm (Rothwell \& Dodgson, 1991).

Hence, these mixed results in the literature show that the relationship between innovation and SMEs performance is complex and requires more research. Nevertheless, despite the probable detrimental effects resulting to an innovation-performance relationship and some conflicting evidences, theory and most of the empirical studies (Gronum et al., 2012; Jiménez-Jiménez \& Sanz-Valle, 2011; Zeng et al., 2010) suggest a positive relationship between innovative activities (product, process, administrative/organizational, technological, incremental and radical innovation) and firm performance. In these contexts, companies with the capacity to innovate will be able to respond to challenges faster and to exploit new products and market opportunities better than non-innovative companies (Brown \& Eisenhardt, 1995; Miles, Snow, Meyer, \& Coleman, 1978).

Innovation helps the company to deal with the turbulence of external environment and, therefore, it is one of the key drivers of long-term success in business, particularly in dynamic markets (Baker \& Sinkula, 2002; Darroch \& McNaughton, 2002). Therefore this study hypothesizes that:

$\mathrm{H} 1$ : There is significant relationship between administrative innovation and firm performance 


\section{Tope Samson Abiodun}

An Examination of the Relationships Between Different Types of Innovation and Firm Performance and the Mediating Effect of Radical and Incremental Innovations on These Relationships

$\mathrm{H} 2$ : There is significant relationship between process innovation and firm performance

H3: There is significant relationship between Product innovation and firm performance

\subsection{Radical Innovation as Mediator}

Mediating variable is a mechanism that transfers the effect of the independent variables on the dependent variable and normally surface as a function of predicting and explaining the influence of independent variables on dependent variables (Hair et al., 2010). Radical innovation and incremental innovation are classification of innovation based on the intensity and scope. Radical innovation gives rise to fundamental changes in the activities of an enterprise and expresses a significant deviation from current practices (Koberg et al., 2003).

This type of innovation is more original and could provoke higher degree of uncertainty for its stage of development and application. Moreover, studies have found significant relationship between radical innovation and firm performance (Baker \& Sinkula, 2002). More importantly, radical innovation shows how extensive and radically changed product innovation, process innovation, administrative innovation, technological innovation, marketing innovation and any other types of innovation could be in a firm (Weerawardena, 2003). An intervening variable is both the product of the independent variable and a cause of the dependent variable and it answers the question how the independent variable influences the dependent variable.

Hence, radical innovation as an intervening variable in this study mediates the relationship between product innovation, process innovation, administrative innovation and firm performance.

$\mathrm{H} 4$ : Radical innovation mediates the relationship between administrative innovation and firm performance.

H5: Radical innovation mediates the relationship between process innovation and firm performance

H6: Radical innovation mediates the relationship between product innovation and firm performance

\subsection{Incremental Innovation as Mediator}

Incremental innovation is relatively small deviation from current practices to improve old products or procedures without necessarily intervening in the existing structure and strategy of the firm (Koberg et al., 2003). In consonant with the function of incremental innovation, mediating variable is the variable that surfaces between the time the independent variable operates to influence the dependent variable and its impact on the dependent variable. This implies that incremental innovation could always manifest between product innovation, process innovation, administrative innovation, technological innovation (independent variables) and firm performance (dependent variable). Moreover, evidence showed that SMEs would focus more on incremental product and process innovations. The liability of smallness and available resources at the disposal of SMEs curtail them to such level of innovation to more extensively exploit the domestic market but cannot support extensive new product development required.

Empirical studies have found incremental innovation to be very important for SMEs and a significant predictor of firm performance (Egbetokun, Olamade, Siyanbola , Adeniyi \& Irefin, 2010). Therefore this study hypothesizes that:

H7: Incremental innovation mediates the relationship between administrative innovation and firm performance.

H8: Incremental innovation mediates the relationship between process innovation and firm performance

H9: Incremental innovation mediates the relationship between product innovation and firm performance. 


\section{Research Methodology}

Research Methodology is the systematic, theoretical analysis of the methods applied to a field of study. This comprises the theoretical analysis of the body of methods and principles associated with a branch of knowledge. Hence, research methodology observed in this study consists of the measures employed, data collection processes, and statistical tools employed.

\subsection{Measures}

Innovation is a process for creating and introducing something new, novel, or advanced with the intention of creating value or benefit (Kearney \& Hisrich, 2014). Innovation has been measured in variety of ways in previous researches, this study employed Manu's (1992) measures on innovation because the measures comprise of proactive and reactive characteristics of innovations. Jimenez-Jimenez et al., (2008) used confirmatory factor analysis on the six items of each product, process and administrative innovations employed by Manu (1992) and suggested three items could be used for product, process and administrative innovation. This study adapted Jimenez- Jimenez et al., (2008) measures of innovation. Table 1 depicts the measures of innovations

Table 1: Measures of Innovations

\begin{tabular}{|c|c|c|c|c|}
\hline Construct & Dimensions & Code & Survey Items & Sources \\
\hline \multirow[t]{9}{*}{ Innovation } & Product & IPO01 & $\begin{array}{l}\text { We often introduce many products in } \\
\text { our firm }\end{array}$ & $\begin{array}{l}\text { Jimenez- } \\
\text { Jimnez } \\
(2008)\end{array}$ \\
\hline & & IPO02 & $\begin{array}{l}\text { Our firm has pioneer disposition to } \\
\text { introduce new products }\end{array}$ & \\
\hline & & IPO03 & $\begin{array}{l}\text { Our firm makes effort in terms of } \\
\text { hours/person, teams and training } \\
\text { involved in innovation }\end{array}$ & \\
\hline & Process & IPP01 & $\begin{array}{l}\text { There are numbers of changes in the } \\
\text { process introduced in our firm }\end{array}$ & \\
\hline & & IPP02 & $\begin{array}{l}\text { We have pioneer disposition to } \\
\text { introduce new process }\end{array}$ & \\
\hline & & IPP03 & $\begin{array}{l}\text { We make quick response to the } \\
\text { introduction of competitors' new } \\
\text { processes in our firm }\end{array}$ & \\
\hline & $\begin{array}{l}\text { Administrativ } \\
\mathrm{e}\end{array}$ & IAO01 & $\begin{array}{l}\text { We have novelty of management } \\
\text { system in our firm }\end{array}$ & \\
\hline & & IAO02 & $\begin{array}{l}\text { Our firm always search for new } \\
\text { management systems }\end{array}$ & \\
\hline & & IAO03 & $\begin{array}{l}\text { Our firm has pioneer disposition to } \\
\text { introduce new management systems }\end{array}$ & \\
\hline
\end{tabular}

The intensity of innovation in a firm is shown through the types of innovations (process, product, administrative and marketing) as limited, marginal improvement (incremental) or extensive, total change (radical). Radical innovation gives rise to fundamental changes in the activities of an enterprise and expresses a significant deviation from current practices (Koberg et al., 2003). This study employed Weerawardena's (2003) measures of radical innovation because it focuses on intensity of different types of innovations. Table 2 depicts the measures of radical innovations. 
Tope Samson Abiodun

An Examination of the Relationships Between Different Types of Innovation and Firm Performance and the Mediating Effect of Radical and Incremental Innovations on These Relationships

Table 2: Measures of Radical Innovation

\begin{tabular}{|c|c|c|c|c|}
\hline Construct & Dimensions & Code & Survey Items & Sources \\
\hline \multirow[t]{7}{*}{ Innovation } & Radical & IRO01 & $\begin{array}{l}\text { Products introduced in } \\
\text { our firm during the past } \\
\text { five years have been } \\
\text { extensive }\end{array}$ & $\begin{array}{l}\text { Weerawardena } \\
(2003)\end{array}$ \\
\hline & & IRO02 & $\begin{array}{l}\text { Process innovation } \\
\text { introduced in our firm } \\
\text { during the past five years } \\
\text { have been extensive }\end{array}$ & \\
\hline & & IRO03 & $\begin{array}{l}\text { In our firm Process } \\
\text { innovation have been } \\
\text { mainly radically change to } \\
\text { production process }\end{array}$ & \\
\hline & & IRO04 & $\begin{array}{l}\text { Managerial innovations } \\
\text { introduced in our firm } \\
\text { during the last five years } \\
\text { have been extensive }\end{array}$ & \\
\hline & & IRO05 & $\begin{array}{l}\text { Managerial innovations } \\
\text { introduced in our firm } \\
\text { have been totally in } \\
\text { managerial practices }\end{array}$ & \\
\hline & & IRO06 & $\begin{array}{l}\text { Marketing innovations } \\
\text { introduced by our firm } \\
\text { during the past five years } \\
\text { have been extensive }\end{array}$ & \\
\hline & & $\begin{array}{l}\text { IRO07 } \\
\text { IR008 }\end{array}$ & $\begin{array}{l}\text { Marketing innovations } \\
\text { introduced have been } \\
\text { totally new marketing } \\
\text { methods. } \\
\text { Service innovation } \\
\text { introduced have been } \\
\text { totally new service } \\
\text { method }\end{array}$ & \\
\hline
\end{tabular}

Incremental innovation is relatively small deviation from current practices to improve old products or procedures without necessarily intervening in the existing structure and strategy of the firm. This study employed Weerawardena's (2003) measures of radical innovation because it focuses on intensity of different types of innovations (process, product, administrative and marketing). Table 3 depicts the measures of incremental innovation.

Table 3: Measures of Incremental Innovation

\begin{tabular}{|l|l|l|l|l|}
\hline Construct & Dimensions & Code & Survey Items & Sources \\
\hline & IIO01 & $\begin{array}{l}\text { Products introduced in our firm } \\
\text { during the past five years have } \\
\text { been limited }\end{array}$ & $\begin{array}{l}\text { Weerardena } \\
(2003)\end{array}$ \\
\hline & IIO02 & $\begin{array}{l}\text { Products improvement in our firm } \\
\text { have been marginal improvement } \\
\text { on the existing method }\end{array}$ & \\
\hline
\end{tabular}


Tope Samson Abiodun

An Examination of the Relationships Between Different Types of Innovation and Firm Performance and the Mediating Effect of Radical and Incremental Innovations on These Relationships

\begin{tabular}{|l|l|l|l|l|}
\hline & IIO03 & $\begin{array}{l}\text { Process innovation introduced in } \\
\text { our firm during the past five years } \\
\text { have been limited }\end{array}$ & \\
\hline & IIO04 & $\begin{array}{l}\text { In our firm Process innovation } \\
\text { have been mainly marginal } \\
\text { improvement on the production } \\
\text { process }\end{array}$ & \\
\hline & IIO05 & $\begin{array}{l}\text { Managerial innovations } \\
\text { introduced in our firm during the } \\
\text { last five years have been limited }\end{array}$ & \\
\hline IIO06 & $\begin{array}{l}\text { Managerial innovations } \\
\text { introduced in our firm have been } \\
\text { mainly marginal improvement in } \\
\text { managerial practices }\end{array}$ & \\
\hline IIO08 & $\begin{array}{l}\text { IIO07 } \\
\text { by our firm during the past five } \\
\text { years have been limited } \\
\text { Service innovations introduced in } \\
\text { our firm during the past five years } \\
\text { have been limited. }\end{array}$ & \\
\hline
\end{tabular}

The measurement of firm performance has not been universally suggested among scholars, Zou, Taylor and Osland (1998) addressed the three critical issues in determining performance, their scale EXPERF was multidimensional and really centered on performance. It was built on Cavusgil and Zou (1994) and comprises three basic dimensions that are rooted in performance's literatures; financial, strategic and satisfaction's performance measure. The nine items adapted from Zou et al., (1998) are used to measure firm performance in this study because they reflect economic and non economic factor that could easily show the performance of SMEs. These nine items adapted from Zou et al., (1998) called EXPERF scale is shown in the Table 4

Table 4: Measures of SMEs Performance

\begin{tabular}{|c|c|c|c|c|}
\hline Construct & Dimension & Code & Survey items & $\begin{array}{l}\text { Source } \\
\text { s }\end{array}$ \\
\hline \multirow[t]{9}{*}{$\begin{array}{l}\text { Firm } \\
\text { Performanc } \\
\text { e }\end{array}$} & Financial & FIN01 & This firm has been very profitable & $\begin{array}{l}\text { Zou et } \\
\text { al., } \\
(1998)\end{array}$ \\
\hline & & FIN02 & $\begin{array}{l}\text { This firm has generated a high } \\
\text { volume of sales. }\end{array}$ & \\
\hline & & FIN03 & This firm has achieved rapid growth. & \\
\hline & Strategy & STG04 & $\begin{array}{l}\text { This firm has improved our global } \\
\text { competitiveness. }\end{array}$ & \\
\hline & & STG05 & $\begin{array}{l}\text { This firm has strengthened our } \\
\text { strategic position. }\end{array}$ & \\
\hline & & STG06 & $\begin{array}{l}\text { This firm has appreciably increased } \\
\text { our global market share. }\end{array}$ & \\
\hline & Satisfaction & SAT07 & $\begin{array}{l}\text { The performance of this firm has been } \\
\text { adequate. }\end{array}$ & \\
\hline & & SAT08 & This firm has been thriving. & \\
\hline & & SAT09 & $\begin{array}{l}\text { This firm has fully met our } \\
\text { expectation. }\end{array}$ & \\
\hline
\end{tabular}




\subsection{Data Collection Process}

The data collection took place in Kano, Nigeria, each of the manufacturing SMEs identified in the directory Manufacturing Association of Nigeria (MAN) was contacted by telephones to identify an appropriate key informant for the study and inform the firm about the research project (Morgan et al., 2004). Almost 700 firms were assessed in three industrial sites extended across the city of Kano. About 550 firms were identified as qualified because they met the criteria specified. To select a sample size for the population of 550, Krejeie and Morgan (1970) sample sizes determination's table was used. The table showed that 226 sample sizes would be required for the population of 550 and additional $40 \%$ of 226 was added making 316 sample sizes to make provision for response bias.

Systematic sampling was used to select 316 owner managers and emailed the questionnaires to their respective email address. About twenty five days after the questionnaire have been emailed to the respondents, 130 completed questionnaires were received through e-mail and these 115 questionnaires were regarded as early responses which (after non useable ones have been removed) were further used to assess non response bias on the actual variables. In order to improve the response rate, a follow-up phone calls and series of Short Message Service (SMS) were sent to remind the owner managers who were yet to return their questionnaires. This effort yielded the largest numbers of response compared to the first response. About 119 questionnaires were returned. It was tagged as late responses which (after non useable ones have been removed) were later used to assess non-response bias. Having removed non useable questionnaires the remaining 334 useable questionnaires show that the study achieved $74 \%$ response rate.

\subsection{Normality Test}

Researchers have suggested that in a large sample of 200 or more, the shape of the graphical distribution should be considered rather than the value of the skewness and kurtosis statistic, as large sample decrease the standard error, which in turn inflate the skewness and kurtosis statistics (Field, 2009)

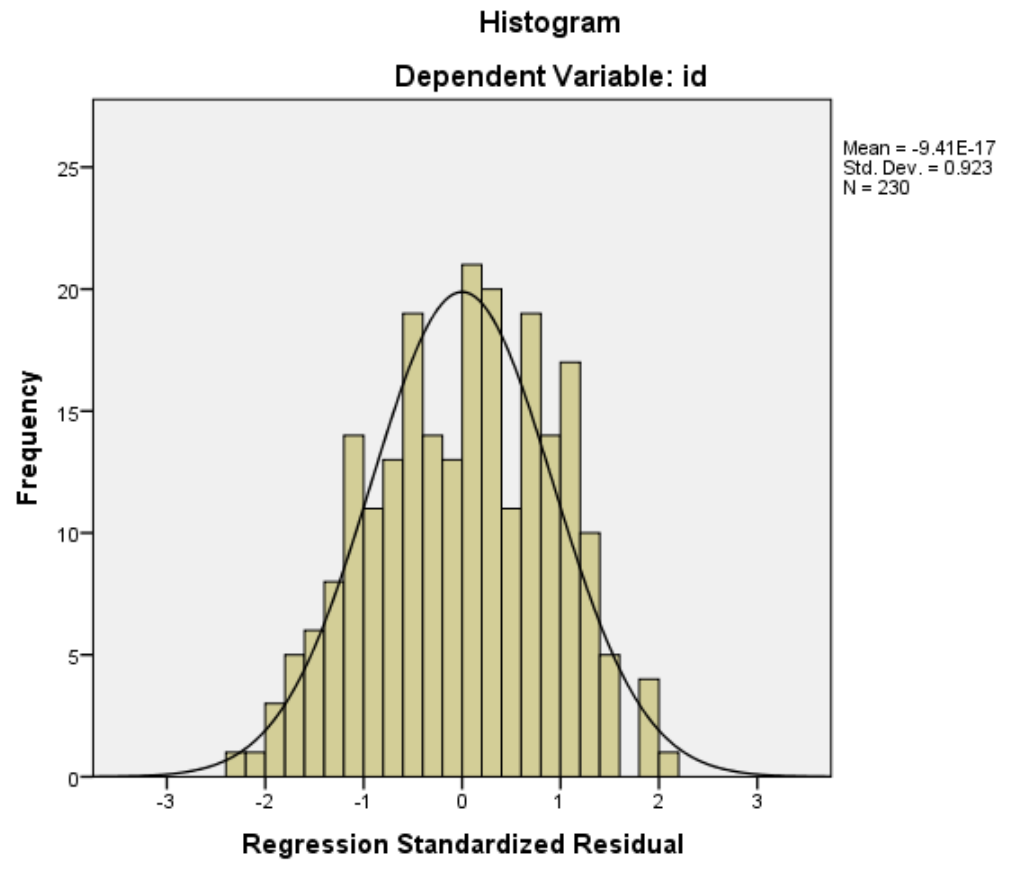




\section{Tope Samson Abiodun}

An Examination of the Relationships Between Different Types of Innovation and Firm Performance and the Mediating Effect of Radical and Incremental Innovations on These Relationships

The present study employed a graphical method to check for the normality of data collected (Tabachnick, \& Fidell). Against this background, the present study used histogram and normal probability to make sure that normality assumptions were not violated. The figure 4.1 shows that data collected for present study reflects normal pattern since all the bars on the histogram were closed to normal curve. Moreover, this is also supported by an inspection of normality probability plot (labeled Normal P-P Plot of Regression Standardized Residual), the observed value for each score is plotted against the expected value from normal distribution. A reasonable straight line suggests normal distribution. Hence, a proof that normality assumptions were not violated.

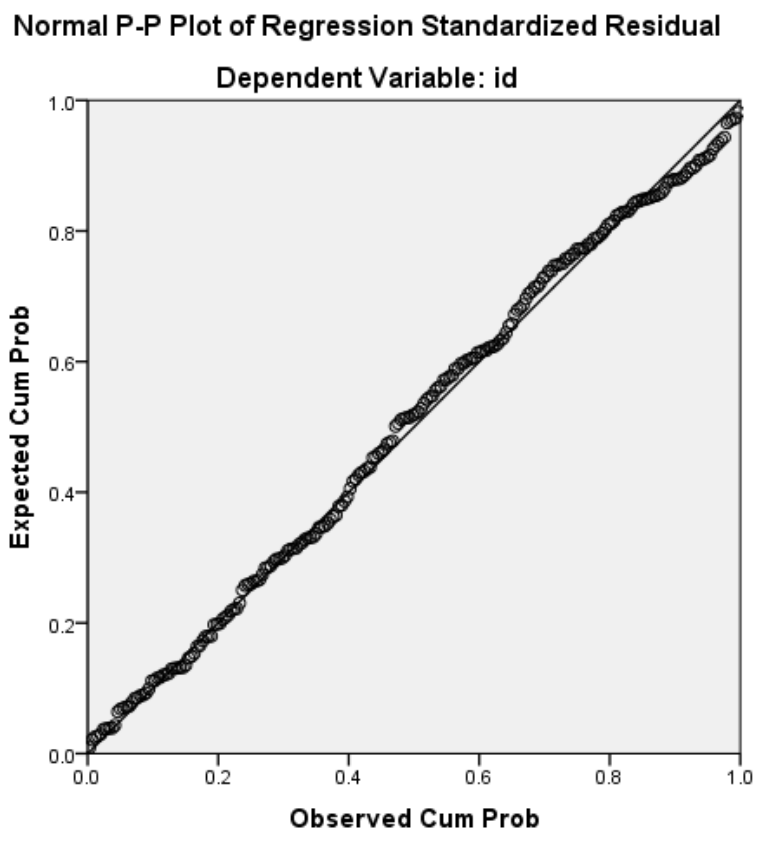

\section{Data Analysis and Interpretation}

This section is organized and presented the results of data analyses using PLS SEM. This comprises of assessment of PLS-SEM path model result; individual item reliability, internal consistency reliability, convergent validity, and validity. The last section presents the assessment of the structural model; assessment of the significant path coefficient, evaluation of the level of R-squared values, determination of effect size, assessment of prediction relevance, and examination of mediation effect.

\subsection{Assessment of PLS-SEM Path Model Result}

Henseler and Sarstedt (2013) suggested in a recent study that goodness of fit (GoF) index is not suitable for validation. Researcher considered Goodness of fit unsuitable because it cannot separate valid model from invalid model (Hair et al., 2013). Against this background, the present study employed a two step process to calculate and report the result of PLS-SEM path as suggested by Henseler, Ringle and Sinkovics (2009). These two-step processes are (1) the assessment of measurement model and (2) the assessment of a structural model (Henseler et al., 2009).

\subsubsection{Assessment of Measurement Model}

Considering the individual item reliability, there was examination of the outer loading of each construct's measure in order to have assessment of individual items reliability (Hair et al., 2012). The indicators with outer loadings between 0.40 and 0.70 are retained, while some items 


\section{Tope Samson Abiodun}

An Examination of the Relationships Between Different Types of Innovation and Firm Performance and the Mediating Effect of Radical and Incremental Innovations on These Relationships

below the threshold of 0.40 are deleted (Hair et al., 2013). About 4 items are deleted out of 34 items. The remaining 30 items are retained as they have loadings that range between 0.633 and 0.963 . The extent at which all items on particular scale are measuring the same concept is referred to as internal consistency reliability (Sun et al., 2007). Composite reliability has been suggested as appropriate measure of internal consistency because it takes to into account the different outer loadings of indicators variables and PLS-SEM gives priority to the indicators according to their individual reliability (Peterson \& kim, 2013). Composite reliability's threshold; Values between 0.70 and 0.90 are considered satisfactory, value above 0.95 is regarded unsuitable and value below 0.60 indicate lack of internal consistency validity (Bernstein \& Nunnally, 1994). Hence, this study composite reliability ranged from 0.766 and 0.941 . Similarly, the rule of thumbs of cut off point of .50 or more on average variance extracted is also achieved because in Table 3.5 the average variance extracted for the constructs ranged from 0.513 and 0.915. Table 4 depicts the composite reliability and average Variance Extracted for the measurement model.

Table 4: Composite Reliability (CR) and Average Variance Extracted (AVE) of the latent Constructs

\begin{tabular}{|l|c|c|}
\hline Constructs & Composite Reliability & $\begin{array}{l}\text { Average Variance Extracted } \\
\text { (AVE) }\end{array}$ \\
\hline $\begin{array}{l}\text { Administrative } \\
\text { Innovation }\end{array}$ & 0.927 & 0.808 \\
\hline Finance & 0.928 & 0.866 \\
\hline Incremental Innovation & 0.922 & 0.704 \\
\hline Process Innovation & 0.930 & 0.915 \\
\hline Product Innovation & 0.941 & 0.891 \\
\hline Radical Innovation & 0.897 & 0.522 \\
\hline Satisfaction & 0.766 & 0.526 \\
\hline Strategy & 0.900 & 0.751 \\
\hline firm Performance & 0.863 & 0.513 \\
\hline
\end{tabular}

This study also shows how discriminant validity was ascertained by comparing the indicator loading with cross loading. Researchers have suggested that the entire indicators should be greater than the cross loading (Hair et al., 2013; Chin, 1998). Table 5 compares the indicator loading with other reflective indicators. All the available indicators are greater than the cross loading, this means the requirement of discriminant validity has been achieved. 
Tope Samson Abiodun

An Examination of the Relationships Between Different Types of Innovation and Firm Performance and the Mediating Effect of Radical and Incremental Innovations on These Relationships

Table 5: Cross Loading Factor Analysis

\begin{tabular}{|c|c|c|c|c|c|c|c|c|}
\hline Variables & Finance & $\begin{array}{l}\text { Admin. } \\
\text { Innovation }\end{array}$ & $\begin{array}{l}\text { Incremental } \\
\text { Innovation }\end{array}$ & $\begin{array}{l}\text { Product } \\
\text { Innovation }\end{array}$ & $\begin{array}{l}\text { Process } \\
\text { Innovation }\end{array}$ & $\begin{array}{l}\text { Radical } \\
\text { Innovation }\end{array}$ & $\begin{array}{l}\text { Satisf- } \\
\text { action }\end{array}$ & Strategy \\
\hline \begin{tabular}{|l|} 
FIN01 \\
\end{tabular} & 0.028 & -0.017 & -0.031 & 0.010 & -0.001 & 0.014 & 0.020 & -0.027 \\
\hline \begin{tabular}{|l|} 
FIN02 \\
\end{tabular} & 0.921 & 0.234 & 0.414 & 0.383 & 0.381 & 0.393 & 0.458 & 0.471 \\
\hline FIN03 & 0.940 & 0.176 & 0.403 & 0.345 & 0.339 & 0.406 & 0.487 & 0.623 \\
\hline IAO01 & 0.168 & 0.840 & 0.408 & 0.437 & 0.410 & 0.424 & 0.213 & 0.045 \\
\hline IAO02 & 0.221 & 0.942 & 0.539 & 0.550 & 0.543 & 0.540 & 0.288 & 0.151 \\
\hline IA003 & 0.195 & 0.913 & 0.477 & 0.503 & 0.453 & 0.519 & 0.255 & 0.103 \\
\hline IIO01 & 0.416 & 0.508 & 0.889 & 0.577 & 0.528 & 0.523 & 0.296 & 0.237 \\
\hline IIO02 & 0.495 & 0.493 & 0.903 & 0.645 & 0.631 & 0.560 & 0.382 & 0.316 \\
\hline IIO03 & 0.322 & 0.451 & 0.872 & 0.497 & 0.486 & 0.490 & 0.274 & 0.224 \\
\hline IIO04 & 0.253 & 0.396 & 0.810 & 0.422 & 0.444 & 0.489 & 0.168 & 0.207 \\
\hline IIO05 & 0.255 & 0.348 & 0.706 & 0.421 & 0.416 & 0.447 & 0.199 & 0.128 \\
\hline IPO01 & 0.357 & 0.525 & 0.603 & 0.921 & 0.819 & 0.548 & 0.318 & 0.200 \\
\hline IPO02 & 0.371 & 0.520 & 0.587 & 0.952 & 0.866 & 0.562 & 0.359 & 0.248 \\
\hline IPO03 & 0.375 & 0.529 & 0.591 & 0.958 & 0.886 & 0.557 & 0.375 & 0.248 \\
\hline IPP01 & 0.361 & 0.493 & 0.595 & 0.888 & 0.945 & 0.536 & 0.355 & 0.229 \\
\hline \begin{tabular}{|l|} 
IPP02 \\
\end{tabular} & 0.381 & 0.524 & 0.577 & 0.859 & 0.963 & 0.559 & 0.382 & 0.256 \\
\hline IPP03 & 0.364 & 0.489 & 0.584 & 0.861 & 0.962 & 0.578 & 0.381 & 0.239 \\
\hline IRO01 & 0.388 & 0.520 & 0.606 & 0.563 & 0.529 & 0.690 & 0.350 & 0.244 \\
\hline IRO02 & 0.229 & 0.230 & 0.262 & 0.284 & 0.284 & 0.633 & 0.167 & 0.049 \\
\hline IRO03 & 0.218 & 0.254 & 0.273 & 0.275 & 0.322 & 0.686 & 0.203 & 0.052 \\
\hline IRO04 & 0.394 & 0.316 & 0.408 & 0.422 & 0.421 & 0.730 & 0.273 & 0.195 \\
\hline IRO05 & 0.242 & 0.401 & 0.344 & 0.315 & 0.327 & 0.674 & 0.206 & 0.080 \\
\hline IRO06 & 0.217 & 0.514 & 0.472 & 0.434 & 0.439 & 0.773 & 0.214 & 0.125 \\
\hline IRO07 & 0.330 & 0.427 & 0.492 & 0.517 & 0.503 & 0.827 & 0.313 & 0.185 \\
\hline IRO08 & 0.385 & 0.402 & 0.440 & 0.440 & 0.426 & 0.751 & 0.329 & 0.233 \\
\hline SAT01 & 0.451 & 0.149 & 0.215 & 0.245 & 0.276 & 0.224 & 0.853 & 0.567 \\
\hline SAT02 & 0.324 & 0.310 & 0.288 & 0.342 & 0.335 & 0.348 & 0.628 & 0.181 \\
\hline \begin{tabular}{|l} 
SAT03 \\
\end{tabular} & 0.296 & 0.298 & 0.323 & 0.329 & 0.319 & 0.374 & 0.675 & 0.184 \\
\hline STG01 & 0.667 & 0.110 & 0.270 & 0.251 & 0.265 & 0.219 & 0.500 & 0.855 \\
\hline STG02 & 0.422 & 0.074 & 0.230 & 0.220 & 0.201 & 0.177 & 0.391 & 0.869 \\
\hline STG03 & 0.431 & 0.114 & 0.224 & 0.165 & 0.184 & 0.175 & 0.456 & 0.875 \\
\hline
\end{tabular}

In the same vein, Table 6 depicts that the square root of the average variance extracted were all greater than the correlation among latent construct, signifying sufficient discriminant validity (Fornell \& Larcker) 
Tope Samson Abiodun

An Examination of the Relationships Between Different Types of Innovation and Firm Performance and the Mediating Effect of Radical and Incremental Innovations on These Relationships

Table 6: Square Root of AVE and Correlation of Latent Constructs

\begin{tabular}{|l|c|c|c|c|c|c|l|l|}
\hline L. Variables & 1 & 2 & 3 & 4 & 5 & 6 & 7 & 8 \\
\hline $\begin{array}{l}\text { Administrative } \\
\text { Innovation }\end{array}$ & $\mathbf{0 . 8 9 9}$ & & & & & & & \\
\hline Finance & 0.218 & $\mathbf{0 . 9 3 0}$ & & & & & & \\
\hline $\begin{array}{l}\text { Incremental } \\
\text { Innovation }\end{array}$ & 0.532 & 0.438 & $\mathbf{0 . 8 3 9}$ & & & & & \\
\hline $\begin{array}{l}\text { Process } \\
\text { Innovation }\end{array}$ & 0.525 & 0.385 & 0.611 & $\mathbf{0 . 9 5 7}$ & & & & \\
\hline $\begin{array}{l}\text { Product } \\
\text { Innovation }\end{array}$ & 0.556 & 0.390 & 0.629 & 0.908 & $\mathbf{0 . 9 4 4}$ & & & \\
\hline $\begin{array}{l}\text { Radical } \\
\text { Innovation }\end{array}$ & 0.554 & 0.430 & 0.600 & 0.583 & 0.589 & $\mathbf{0 . 7 2 3}$ & & \\
\hline $\begin{array}{l}\text { Satisfaction } \\
\text { Strategy }\end{array}$ & 0.283 & 0.509 & 0.333 & 0.390 & 0.372 & 0.371 & $\mathbf{0 . 7 2 5}$ & \\
\hline
\end{tabular}

\subsection{Assessment of Structural Model}

Having confirmed that the construct measures are reliable and valid, the next line of action in this study was to address the assessment of the structural model result. Standard bootstrapping procedure was used with a number of 5000 bootstrap samples and 234 cases.

Table 7: The Result of Path Model

\begin{tabular}{|l|r|r|r|r|}
\hline Relationship & $\beta$ & \multicolumn{1}{|c|}{ (STDEV) } & T Statistics & P Values \\
\hline $\begin{array}{l}\text { Administrative } \\
\text { Innovation -> Firm } \\
\text { performance }\end{array}$ & 0.301 & 0.074 & $4.064^{* * *}$ & 0.000 \\
\hline $\begin{array}{l}\text { Process Innovation } \\
->\text { firm } \\
\text { performance }\end{array}$ & 0.233 & 0.129 & $1.808^{*}$ & 0.071 \\
\hline $\begin{array}{l}\text { Product Innovation } \\
->\text { firm } \\
\text { performance }\end{array}$ & 0.218 & 0.142 & $1.535^{*}$ & 0.125 \\
\hline
\end{tabular}

Note: Significant level; $* \mathrm{P}<0.1 ; * * \mathrm{P}<0.05 ; * * * \mathrm{P}<0.01$ (1-tailed test)

Table 7 summarizes the results of direct relationship of reflective measured constructs, administrative innovation, process innovation, product innovation, and firm performance by showing the original outer weights estimates, the $t$ values and the corresponding significance levels marked in asterisks as well as the $\mathrm{p}$ values. Hypothesis 1 predicted that administrative innovation is significantly related to firm performance, the outcome of PLS model's estimate $(\beta=.301, t=4.064, p<.0 .000)$ showed that the prediction was supported. Hypothesis 2 predicted that there is significant relationship between process innovation and firm performance. The finding on the relationship $(\beta=.0 .233, t=1.808, P=<0.071)$ supported the hypothesis. In the same vein, hypothesis 3 predicted that product innovation is significantly related to firm performance, the result of PLS model's estimate showed $(\beta=.218, t=1.535, p=0.125)$ support for the relationship. 


\section{Tope Samson Abiodun}

An Examination of the Relationships Between Different Types of Innovation and Firm Performance and the Mediating Effect of Radical and Incremental Innovations on These Relationships

\subsection{Mediating Effect}

The real mediation effect in PLS model was examined by means of the bootstrapping procedure in tandem along with proposed hypotheses (Hair et al., 2013), Generally, mediation could be assessed by multiplying the average of paths for instance " $a$ " and " $b$ " and proceed to divide the obtained value by standard error of the paths (Kock, 2011). Table 8 depicts the template for mediation calculation for the present study

Sobel test equation

$z$-value $=a * b / S Q R T\left(b^{2 *} s a^{2}+a^{2 *} s b^{2}\right)$

Table 7: The result of Mediation (Radical Innovation) calculation

\begin{tabular}{|l|l|l|l|l|l|l|l|}
\hline Hypotheses & Relationship & Path A & Path B & $\beta$ & STDERR & T. Value & Decision \\
\hline H4 & $\begin{array}{l}\text { Admin } \\
\text {->Rad->FP }\end{array}$ & 0.344 & -0.024 & 0.003 & 0.003 & $2.964^{* *}$ & Supported \\
\hline H5 & $\begin{array}{l}\text { Process } \\
->\text { Rad- } \\
->\text { FP }\end{array}$ & 0.219 & -0.024 & 0.148 & 0.003 & $1.504^{*}$ & supported \\
\hline H6 & $\begin{array}{l}\text { Product } \\
\text {->Rad- } \\
\text {->FP }\end{array}$ & 0.242 & -0.024 & 0.003 & 0.001 & $2.928^{* *}$ & supported \\
\hline
\end{tabular}

Note: Significant level; $* \mathrm{P}<0.1 ; * * \mathrm{P}<0.05 ; * * * \mathrm{P}<0.01$ (1-tailed test)

The result (STDERR $=0.003, \mathrm{t}=2.964 * *, \beta=0.003$ ) of $\mathrm{H} 4$ in Table 9 depicts that radical innovation mediate the relationship between administrative innovation and firm performance, similarly, the result (STDERR $=0.003, T=1.504 *, \beta=0.148$ ) of $\mathrm{H} 5$ shows that radical innovation mediates the relationship between process innovation and firm performance. And also the result (STDERR $=0.001, \mathrm{~T}=2.928^{* *}, \beta=0.003$ ) of $\mathrm{H} 6$ reveals that radical innovation mediates the relationship between product innovation and firm performance.

Table 8: The result of Mediation (Incremental Innovation) Calculation

\begin{tabular}{|l|l|l|l|l|l|l|l|}
\hline H & Relationships & Path a & Path b & $\boldsymbol{\beta}$ & SE & T-v & Decision \\
\hline H7 & Admin->IIN->FP & -0.181 & 0.363 & -0.066 & 0.053 & -1.231 & N/supported \\
\hline H8 & PROC->IIN->FP & 0.313 & 0.363 & 0.114 & 0.034 & $\begin{array}{l}3.353^{*} \\
* *\end{array}$ & Supported \\
\hline H9 & PROD->IIN->FP & 0.230 & 0.363 & 0.083 & 0.041 & $\begin{array}{l}2.013^{*} \\
*\end{array}$ & supported \\
\hline
\end{tabular}

Note: Significant level; $* \mathrm{P}<0.1 ; * * \mathrm{P}<0.05 ; * * * \mathrm{P}<0.01$ (1-tailed test)

The result (STDERR $=0.053, \mathrm{t}=-1.231, \beta=-0.066$ ) of $\mathrm{H} 7$ in Table 4.6 shows that incremental innovation did not mediate the relationship between administrative innovation and firm performance, however, the result (STDERR $=0.034, t=3.353^{* * *}, \beta=0.114$ ) of H8 supports the proposition that incremental innovation mediates the relationship between process innovation and firm performance. And also the result (STDERR $=0.041, t=2.013^{* *}, \beta=0.083$ ) of $\mathrm{H} 9$ reveals that incremental innovation mediates the relationship between product innovation and firm performance. 


\subsection{Variance Explained in the Endogenous Variable}

This study also employed coefficient of determination ( $R^{2}$ value) as one of the criteria to assess the structural model in PLS-SEM (Hensler et al., 2009). R- Squared is a measure of the proportion of an endogenous construct's variance that is explained by its predictor construct (Hair et al., 2013). The acceptable level of $R^{2}$ values are $0.25,0.50,0.75$ for endogenous variable and could be described as weak, moderate, or substantial (Hair, Ringle, \& Sarsted, 2011). While minimum acceptable levels of $R$ squared by scholars like Falk and Miller (1992) is 0.10 .

Table 4.7 depicts the measure of the proportion of firm performance, radical innovation, and incremental innovation (endogenous variables) that are explained by predicting constructs.

Table 9: Variance Explained in the Endogenous Variable

\begin{tabular}{|c|c|}
\hline Latent Variables & Variance Explained ( $\left.\mathbf{R}^{\mathbf{2}}\right)$ \\
\hline Radical Innovation & $43 \%$ \\
\hline Incremental Innovation & $53 \%$ \\
\hline Firm Performance & $99 \%$ \\
\hline
\end{tabular}

As shown in table 4.9 the research model explained $43 \%$ of the total variance in radical innovation, $53 \%$ in incremental innovation and $99 \%$ of the variance in firm performance. This implies that radical innovation, incremental innovation, product innovation, process innovation and administrative innovation collectively explained $99 \%$ of the variance in endogenous variable (firm performance), while the three exogenous latent variables ( product innovation, process innovation and administrative innovation) explained $43 \%$ and $53 \%$ of the variance in radical and incremental endogenous variables. Thus, using the criteria of Falk and Miller (1992) and Chin (1998), radical innovation and incremental innovation (endogenous variables) could be considered moderate while firm performance (endogenous variable) could be considered substantial.

\section{Conclusion and Recommendations}

One of the major objectives of this study is to draw a direct relationship between types of innovation (administrative innovation, process innovation \& product innovation) and firm performance (SMEs' performance). Even though, innovation-performance relationship frequently presents mixed finding in several empirical studies (Birley \& Westhead 1990; Heunks 1998; McGee et al., 1995; Vermeulen, 2005). This study has found positive significant relationships between administrative innovation, process innovation \& product innovation and firm performance; which is consistent with prior researches (Therrient et al 2011:Artz et al., 2011; Jimenez-Jimenez, 2011; Atalay et al., 2013; Hung \& Chou 2013; Ar et al.,2012; Lööf \& Heshmati 2006; Jimenez-Jimenez, 2011; Zeng Xie \&Tam, 2010; Chao and Pucik, 2005; Gronum et al., 2012; Ahn et al., 2014; (Jaske, 2011). However, there is a higher incidence for administrative innovation than process innovation and slightly higher incidence of process innovation than product innovation in the significant level of 1 - tail test conducted.

The managerial implication, since the measures adopted examined the numbers and proportion of firms that indicated an increase in their profit, satisfaction and market share when employed these types of innovation- which speaks of improved product quality. It is obvious that, most of the SMEs in the sample had seen improvements in their performance, which is more pronounced in profit and market share. The importance of innovation is confirmed and empirical support is provided for the encouragement of innovation in SMEs. This is consistent with the view that firms with the capacity to innovate will be able to respond to challenges faster and to exploit new products and market opportunities better than non-innovative companies (Brown \& 


\section{Tope Samson Abiodun}

An Examination of the Relationships Between Different Types of Innovation and Firm Performance and the Mediating Effect of Radical and Incremental Innovations on These Relationships

Eisenhardt, 1995; Miles, Snow, Meyer, \& Coleman, 1978). Innovation helps the company to deal with the turbulence of external environment and, therefore, it is one of the key drivers of long-term success in business, particularly in dynamic markets (Baker \& Sinkula, 2002; Darroch \& McNaughton, 2002). What matters is that the firm chooses to pursue such innovations that most fit its strategies and available resources

Similarly, Table 4.5 depicts that radical innovation mediate the relationship between administrative innovation and firm performance, the result (STDERR $=0.003, T=1.504 *, \beta=$ 0.148 ) of $\mathrm{H} 5$ also shows that radical innovation mediates the relationship between process innovation and firm performance. And also the result (STDERR $=0.001, T=2.928^{* *}, \beta=0.003$ ) of $\mathrm{H} 6$ reveals that radical innovation mediates the relationship between product innovation and firm performance. This is consistent with the proposition of this study that radical innovation is more original and could provoke higher degree of uncertainty for its stage of development and application. Moreover, studies have found significant relationship between radical innovation and firm performance (Baker \& Sinkula, 2002). More importantly, radical innovation shows how extensive and radically changed product innovation, process innovation, administrative innovation, technological innovation, marketing innovation and any other types of innovation could be employed in a firm (Weerawardena, 2003). The mediation of radical innovation in the relationship between types of innovation and firm performance implies that radical innovation forces the management of administrative, product and process innovation to ask a new set of questions, to draw on new technical and commercial skills, and to employ new problem-solving approaches to improve the performance of SMEs.

Hence, when SMEs' innovation is based on a different set of engineering and scientific principles and often opens up the whole new markets and potential applications. It might often create great difficulties for established firms and can be the basis for the successful entry of new firms or even the redefinition of an industry (Dess and Beard, 1984)

In the same manner, the result (STDERR $=0.034, t=3.353^{* * *}, \beta=0.114$ ) of H8 supports the proposition that incremental innovation mediates the relationship between process innovation and firm performance. And also the result (STDERR $=0.041, t=2.013 * *, \beta=0.083$ ) of $\mathrm{H} 9$ reveals that incremental innovation mediates the relationship between product innovation and firm performance. This could be interpreted as incremental innovation coupled with process/product innovation could enhance firm performance. The statistical significance of these relationships is in consistent with prior studies that incremental innovation often calls for considerable skill and ingenuity and, over time, has very significant economic consequences, this implies that incremental innovation could always manifest between product innovation, process innovation and firm performance. Moreover, evidence showed that SMEs would focus more on incremental product and process innovations. The liability of smallness and available resources at the disposal of SMEs curtail them to such level of innovation to extensively exploit the domestic market but cannot support extensive new product development required.

On the Contrary, the result (STDERR $=0.053, \mathrm{t}=-1.231, \beta=-0.066$ ) of $\mathrm{H} 7$ in Table 4.8 shows that incremental innovation did not mediate the relationship between administrative innovation and firm performance, which is contrary to the hypothesized relationship, this could mean administrative innovation coupled with incremental intensity might not necessarily improve firm performance, but this insignificant relationship could also means different dimensions of innovation coupled with incremental innovation might serve a different purpose or effect on firm performance, and each dimension could vary independently (Lumpkin \& Dess, 1996b). The influence of incremental innovation and administrative innovation on firm performance might vary as a function of cultural norms. Nevertheless, incremental innovation and administrative innovation delayed effect on firm performance might have been responsible for this insignificant result. Longitudinal design may be used by future studies to address the effect of this delay. 


\section{Tope Samson Abiodun}

An Examination of the Relationships Between Different Types of Innovation and Firm Performance and the Mediating Effect of Radical and Incremental Innovations on These Relationships

This study is an attempt to investigate the types and impact of innovation on SMEs in developing economies. The study is particularly distinguished, because there have been many studies examining the relationship between innovation and firm performance, but, the present study addressed the theoretical gap by employing radical and incremental innovation as mediators. The theoretical framework of the study has added to the domain of innovation capabilities view and entrepreneurship. The results of the study suggest product innovation, process innovation and administrative innovation are statistically significant and positively related to firm performance. Radical innovation mediates the relationship between process, product, administrative innovation and firm performance. Incremental innovation mediates the relationship between process, product and firm performance. While the study finds no support for the proposition that incremental innovation mediates the relationship between administrative innovation and firm performance.

In addition to the theoretical contributions, the findings of this study provide some important practical implications to SMEs, managers and policy makers. Therefore, managers who put relatively more emphasis on profitability could invest more on radical innovation. Even though some prior studies generally found out that radical innovation seems more complicated to SMEs because it is more original and could provoke higher degree of uncertainty for its stage of development, on the contrary, this study has found out despite the liabilities of smallness of SMEs and other limitations that when radical innovation is coupled with product, process and administrative innovation there would be improvement in firm performance.

Further studies with larger samples in different countries/ context would be very useful in facilitating cross-country comparison. Also, longitudinal studies would help in throwing light on how sectoral characteristics influence the types of innovation that SMEs pursue.

\section{References}

- Anokhin, S., \& Schulze, W. S. (2009). Entrepreneurship, innovation, and corruption. Journal of Business Venturing, 24(5), 465-476Ar, I. M. (2012). The impact of green product innovation on firm performance and competitive capability: the moderating role of managerial environmental concern. Procedia-Social and Behavioral Sciences, 62, 854-864.

- Artz, K. W., Norman, P. M., Hatfield, D. E., \& Cardinal, L. B. (2010). A longitudinal study of the impact of $\quad R \& D$, patents, and product innovation on firm performance. Journal of Product Innovation Management, 27(5), 725-740. Crossref

- Atalay, M., Anafarta, N., \& Sarvan, F. (2013). The relationship between innovation and firm performance: An empirical evidence from Turkish automotive supplier industry. Procedia-Social and Behavioral Sciences, 75, 226-235. Crossref

- Baker, W. E., \& Sinkula, J. M. (2002). Market orientation, learning orientation and product innovation: delving into the organization's black box. Journal of market-focused management, 5(1), 5-23 Crossref

- Bernstein, I. H., \& Nunnally, J. (1994). Psychometric theory. New York: McGraw-Hill.

- Birley, S., \& Westhead, P. (1990). Growth and performance contrasts between 'types' of small firms. Strategic Management Journal, 11(7), 535-557. Crossref

- Black, D., \& Synan, C. (1997). The learning organisation: the sixth discipline? Management Accounting-London-, 75, 70-75.

- Brown, S. L., \& Eisenhardt, K. M. (1995). Product development: Past research, present findings, and future directions. Academy of management review, 20(2), 343-378.

- Carayannis, E. G., Samara, E. T., \& Bakouros, Y. L. (2015a). Innovation and Competitiveness: Case Study Innovation and Entrepreneurship (pp. 47-72): Springer.

- Carayannis, E. G., Samara, E. T., \& Bakouros, Y. L. (2015b). Introduction to Innovation Management Innovation and Entrepreneurship (pp. 27-46): Springer. 


\section{Tope Samson Abiodun}

An Examination of the Relationships Between Different Types of Innovation and Firm Performance and the Mediating Effect of Radical and Incremental Innovations on These Relationships

- Cavusgil, S. T., \& Zou, S. (1994). Marketing strategy-performance relationship: an investigation of the empirical link in export market ventures. The Journal of Marketing, 121. Crossref

- Chin, W. W. (1998). Commentary: Issues and opinion on structural equation modeling: New Jersey: Laurence Erlbaum Associates

- Cho, H.-J., \& Pucik, V. (2005). Relationship between innovativeness, quality, growth, profitability, and market value. Strategic management journal, 26(6), 555-575. Crossref

- Christensen, C., \& Raynor, M. (2013). The innovator's solution: Creating and sustaining successful growth: Harvard Business Review Press.

- Cohen, W. M., \& Klepper, S. (1996). A reprise of size and R \& D. The Economic Journal, 925951 Crossref

- Damanpour, F., Szabat, K. A., \& Evan, W. M. (1989). The relationship between types of innovation and organizational performance. Journal of Management Studies, 26(6), 587-602 Crossref

- Darroch, J., \& McNaughton, R. (2002). Examining the link between knowledge management practices and types of innovation. Journal of intellectual capital, 3(3), 210-222 Crossref

- Deeds, D. L., \& Decarolis, D. M. (1999). The impact of stocks and flows of organizational knowledge on firm performance: An empirical investigation of the biotechnology industry. Strategic management journal.

- Delgado-Verde, M., Martín-de Castro, G., \& Emilio Navas-López, J. (2011). Organizational knowledge assets and innovation capability: Evidence from Spanish manufacturing firms. Journal of intellectual capital, 12(1), 5-19. Crossref

- Dewar, R. D., \& Dutton, J. E. (1986). The adoption of radical and incremental innovations: An empirical analysis. Management science, 32(11), 1422-1433. Crossref

- Drejer, A. (2002). Situations for innovation management: towards a contingency model. European Journal of Innovation Management, 5(1), 4-17. Crossref

- Egbetokun, A., Siyanbola, W., \& Adeniyi, A. (2007). Assessment of Innovation Capability in the Cable and Wire Manufacturing Industry in Nigeria: a case study approach. Proceedings of Micro Evidence on Innovation in Developing Economies [MEIDE], UNU-MERIT, Maastricht, May.

- Feldman, M. P., \& Florida, R. (1994). The geographic sources of innovation: technological infrastructure and product innovation in the United States. Annals of the Association of American Geographers, 84(2), 210-229. Crossref

- Fiegenbaum, A., \& Karnani, A. (1991). Advantage for Small Firms. Strategic Management J ournal, 12, 101-114. Crossref

- Freeman, C. (1982). The economics of industrial innovation.

- Gronum, S., Verreynne, M. L., \& Kastelle, T. (2012). The Role of Networks in Small and Medium-Sized Enterprise Innovation and Firm Performance. Journal of Small Business Management, 50(2), 257-282. Crossref

- Heunks, F. J. (1998). Innovation, creativity and success. Small Business Economics, 10(3), 263-272. Crossref

- Howell, J. M., Shea, C. M., \& Higgins, C. A. (2005). Champions of product innovations: defining, developing, and validating a measure of champion behavior. Journal of business venturing, 20(5), 641-661. Crossref

- Hung, K.-P., \& Chou, C. (2013). The impact of open innovation on firm performance: The moderating effects of internal R\&D and environmental turbulence. Technovation, 33(10), 368-380. Crossref

- Jaskyte, K. (2011). Predictors of administrative and technological innovations in nonprofit organizations. Public Administration Review, 71(1), 77-86 Crossref

- Jiménez-Jiménez, D., \& Sanz-Valle, R. (2011). Innovation, organizational learning, and performance. Journal of business research, 64(4), 408-417. Crossref 


\section{Tope Samson Abiodun}

An Examination of the Relationships Between Different Types of Innovation and Firm Performance and the Mediating Effect of Radical and Incremental Innovations on These Relationships

- Kafouros, M. I., Buckley, P. J., Sharp, J. A., \& Wang, C. (2008). The role of internationalization in explaining innovation performance. Technovation, 28(1), 63-74. Crossref

- Kearney, C., \& Hisrich, R. D. (2014). 6. Entrepreneurship in developing economies: transformation, barriers and infrastructure. Necessity Entrepreneurs: Microenterprise Education and Economic Development, 103.

- Keskin, H. (2006). Market orientation, learning orientation, and innovation capabilities in SMEs: An extended model. European Journal of Innovation Management, 9(4), 396-417. Crossref

- Kleinknecht, A., Van Montfort, K., \& Brouwer, E. (2002). The non-trivial choice between innovation indicators. Economics of Innovation and new technology, 11(2), 109-121. Crossref

- Klette, T. J., \& Kortum, S. (2002). Innovating firms and aggregate innovation: National Bureau of Economic Research. Crossref

- Koberg, C. S., Detienne, D. R., \& Heppard, K. A. (2003). An empirical test of environmental, organizational, and process factors affecting incremental and radical innovation. The Journal of High Technology Management Research, 14(1), 21-45. Crossref

- Kwoh, L. (2012). You call that innovation? The Wall Street Journal, 23.

- Lages, L. F., Silva, G., \& Styles, C. (2009). Relationship capabilities, quality, and innovation as determinants of export performance. Journal of International Marketing, 17(4), 47-70. Crossref

- Lee, R. P., \& Chen, Q. (2009). The immediate impact of new product introductions on stock price: the role of firm resources and size. Journal of Product Innovation Management, 26(1), 97-107.Crossref

- Lee, T.-S., \& Tsai, H.-J. (2005). The effects of business operation mode on market orientation, learning orientation and innovativeness. Industrial Management \& Data Systems, 105(3), 325-348. Crossref

- Li, H., \& Atuahene-Gima, K. (2001). Product innovation strategy and the performance of new technology ventures in China. Academy of Management Journal, 44(6), 1123-1134. Crossref

- Lööf, H., \& Heshmati, A. (2006). On the relationship between innovation and performance: A sensitivity analysis. Economics of Innovation and New Technology, 15(4-5), 317-344. Crossref

- Manu, F. A. (1992). Innovation orientation, environment and performance: A comparison of US and European markets. Journal of International Business Studies, 23(2), 333-359. Crossref

- Miles, R. E., Snow, C. C., Meyer, A. D., \& Coleman, H. J. (1978). Organizational strategy, structure, and process. Academy of management review, 3(3), 546-562.

- Moch, M. K., \& Morse, E. V. (1977). Size, centralization and organizational adoption of innovations. American sociological review, 716-725. Crossref

- Nelson, R. R., \& Winter, S. G. (2002). Evolutionary theorizing in economics. The journal of economic perspectives, 16(2), 23-46. Crossref

- Oyewale, A. (2005). Addressing the research-industry linkage impasse in Nigeria: The critical issues and implementation strategies. Globelics-South Africa.

- Rothwell, R., \& Dodgson, M. (1991). External linkages and innovation in small and mediumsized enterprises. R\&D Management, 21(2), 125-138. Crossref

- Salavou, H., \& Lioukas, S. (2003). Radical product innovations in SMEs: the dominance of entrepreneurial orientation. Creativity and Innovation Management, 12(2), 94-108. Crossref

- Scholl, G., Rubik, F., Kalimo, H., Biedenkopf, K., \& Söebech, Ó. (2010). Policies to promote sustainable consumption: innovative approaches in Europe. Paper presented at the Natural resources forum. Crossref

- Schumpeter, J. A. (1934). The theory of economic development: An inquiry into profits, capital, credit, interest, and the business cycle (Vol. 55): Transaction publishers 


\section{Tope Samson Abiodun}

An Examination of the Relationships Between Different Types of Innovation and Firm Performance and the Mediating Effect of Radical and Incremental Innovations on These Relationships

- Singh, J. V., \& Lumsden, C. J. (1990). Theory and research in organizational ecology. Annual review of sociology, 161-195. Crossref

- Therrien, P., Doloreux, D., \& Chamberlin, T. (2011). Innovation novelty and (commercial) performance in the service sector: a Canadian firm-level analysis. Technovation, 31(12), 655-665. Crossref

- Tushman, M. L., \& Anderson, P. (1986). Technological discontinuities and organizational environments. Administrative science quarterly, 439-465. Crossref

- Wang, Z., \& Wang, N. (2012). Knowledge sharing, innovation and firm performance. Expert systems with applications, 39(10), 8899-8908. Crossref

- Weerawardena, J. (2003). Exploring the role of market learning capability in competitive strategy. European journal of marketing, 37(3/4), 407-429. Crossref

- Weerawardena, J. (2003). The role of marketing capability in innovation-based competitive strategy. Journal of strategic marketing, 11(1), 15-35. Crossref

- Zeng, S. X., Xie, X., \& Tam, C. M. (2010). Relationship between cooperation networks and innovation performance of SMEs. Technovation, 30(3), 181-194. Crossref

- ZHANG, X.-d., \& ZHU, Q. (2007). The Favorable Interaction of Firms' Innovation and Market Power Formation in Global Value Chain [J]. China Industrial Economy, 5.

- Zheng, Y., Liu, J., \& George, G. (2010). The dynamic impact of innovative capability and inter-firm network on firm valuation: A longitudinal study of biotechnology start-ups. Journal of Business Venturing, 25(6), 593-609 Crossref 